\title{
Aroclor 1254 Toxicity to Mice Liver Membrane Atpases
}

\author{
Shweta Pathak and Rahul Kundu \\ Department of Biosciences, Saurashtra University, Rajkot-360005, Gujarat State, India
}

Received 2012-05-08, Revised 2012-09-06; Accepted 2013-07-13

\begin{abstract}
Present communication reports the sub-acute dose and exposure duration dependent effects of Aroclor 1254 on total, $\mathrm{Na}^{+}, \mathrm{K}^{+}, \mathrm{Ca}^{++}$and $\mathrm{Mg}^{++}$-ATPases of the mouse liver cells. The study tests two hypotheses, (a) whether the sublethal dose or the exposure duration dependent in vivo exposure of hydrophobic PCB (Aroclor 1254) affects the hydrophilic membrane-bound ion dependent ATPases of the liver cells and (b) if a response was observed, whether it was a direct effect of the toxicant on the membrane bound enzymes systems. To check these hypotheses, two groups of mice were subjected to different sublethal oral doses ( 0.1 and $\left.1 \mathrm{mg} \mathrm{kg}^{-1} \mathrm{bw} \mathrm{d}\right)^{-1}$ ) of Aroclor 1254 for three exposure durations (4, 8 and 12 days). Specific activities of four membrane bound ATPases were estimated from the liver tissue of the aroclor treated mice and compared with a control. Results indicated significant dose as well as duration dependent changes in the enzymatic levels in the hepatic cells of the exposed mice. In most of the cases, the enzyme activity was initially inhibited followed by stimulation after longer exposure duration. The observations suggested that the alteration in the enzyme activity was possibly due to the oxidative stress generated by Aroclor 1254. The results indicated that the membrane bound hydrophilic ATPases were indeed affected by the hydrophobic Aroclor, but the effects were possibly indirect through complex chain of reactions exhibited by the cells.
\end{abstract}

Keywords: Aroclor 1254, Liver, ATPases, Bound Hydrophilic, Commercial Mixture, Duration Dependent, Enzymes Systems, Observations Suggested, Present Communication

\section{INTRODUCTION}

PCBs are very stable and strongly lipophilic compounds. These are persistent in the ecosystem, bio-concentrated through the food chain due to their affinity for lipids and resistance to metabolism. Some congeners and metabolites of PCBs have a variety of toxicological effects in mammals, particularly with chronic exposure (Hansen, 1994). Aroclors are reported to be readily absorbed in soil, remains immobile during leaching process and highly mobile in the presence of organic solvents (Lu, 1989). Oral $\mathrm{LD}_{50}$ values for Aroclor 1254 are reported to be 1295 $\mathrm{mg} \mathrm{kg}^{-1}$ day in male Osborne-Mendel rats, $1010 \mathrm{mg}$ $\mathrm{kg}^{-} 1$ day in Sherman rats and $4000 \mathrm{mg} \mathrm{kg}^{-1}$ day in the mink (ATSDR, 1995). PCBs show a higher affinity for liver than other adipose tissue when compared to those PCB congeners which have chlorine atoms in ortho positions (Yoshimura et al., 1985; Van Birgelen, 1994). The increased affinity of Aroclor to liver is possibly associated with induction of hepatic binding proteins. It was reported earlier that rats exposed to sublethal dose of Aroclor 1254 in the diet for 4 days exhibited increased relative liver weight and increased serum cholesterol (Carter, 1985). Hepatic vacuolar degeneration with decreased weight was observed in rats exposed to sublethal doses of Aroclor 1254 through diet (Carter and Koo, 1984). Price et al. (1988) reported that rats exposed to $7.5 \mathrm{mg} \mathrm{kg}^{-1}$ day dose of Aroclor 1254 in the diet for 7 days showed increased relative liver weight, decreased liver glucose 6-phosphatase activity and decreased serum

Corresponding Author: Rahul Kundu, Department of Biosciences, Saurashtra University, Rajkot-360005, Gujarat State, India Fax: + 912812576347 
$\mathrm{T}_{4}$ hormone levels. The activity of $\mathrm{Na}^{+}, \mathrm{K}^{+}$-ATPase and $\mathrm{Mg}^{++}$ATPase from several fish tissues were reported to be inhibited by PCBs (Koch, 1972). It was also reported that the administration of commercial PCBs, as well as purified isomers to rats inhibited the total ATPase activity in the liver, kidney and brain tissues (Hale et al., 2003). LaRocca and Carlson (1979) reported a strong negative correlation between PCB-induced inhibition of ATPases and solubility of the PCBs. Enormous organismic as well as tissue differences in susceptibility to the individual Aroclor compound were reported in the literature which leads to the selection of wide dose and exposure duration ranges in the contemporary studies using different animal models (ATSDR, 1995). Mode of administration and exposure durations also reported to be responsible for interspecific differences in the absorption, metabolism and toxicity of individual Aroclor compound (ATSDR, 1995). The present communication tests two hypotheses that (a) whether the sublethal dose or the exposure duration dependent in vivo exposure of hydrophobic PCB (Aroclor 1254) affects the hydrophilic membrane-bound ion dependent ATPases of the liver cells and (b) if a response was observed, whether it was a direct effect of the toxicant on the membrane bound enzymes systems.

\section{MATERIALS AND METHODS}

Adult male Swiss albino mice, around 2 months of age and weighing 30-40g, were used for the study. Three groups of animals were provided with rodent diet and water ad libitum, kept under standard conditions and experiments were conducted according to the ethical norms of CPCSEA, India (CPCSEA/CH/RF/ACK2003). Adult male Swiss albino mice were intoxicated with an oral administration of Aroclor 1254 (Sigma) in 0.1 and $1 \mathrm{mg} \mathrm{kg}^{-1}$ body weight/day doses, dissolved in corn oil (Sigma) for three different exposure durations (4, 8 and 12 days). The selection of the doses were based on the available reports of non-carcinogenic effects in the liver tissue of mice, especially on the enzymes (acute to sub-acute exposure) and evaluation of toxicity studies and application of factors (LOAEL) for extrapolating from animal model to human for Aroclor 1254 administered through oral route (ATSDR, 1995). A separate control group was also maintained with daily dose of vehicle only. After toxic exposure, the liver was quickly harvested and washed in ice cold distilled water and homogenized in a Potter-Elvehjem glass homogenizer at $0-4^{\circ} \mathrm{C}$ in Sucrose-EDTA-Imidazole buffer to make a $10 \%(\mathrm{w} / \mathrm{v})$ tissue concentration. Extraction and assay of total, $\mathrm{Na}^{+}-\mathrm{K}^{+}, \mathrm{Ca}^{++}$and $\mathrm{Mg}^{++}$ATPases were done as per the method of Zaugg (1982) with appropriate modifications (Lakshmi et al., 1991). Resulting inorganic phosphate was measured by the method of Fiske and Subbarow (1952). Protein content in the tissue extract was estimated by the method of Lowry et al. (1951). The obtained data were subjected to various statistical analyses like ANOVA and Student's t-test, wherever necessary, for their cumulative acceptability. All statistical procedures were computed as per Sokal and Rohlf (1969).

\section{RESULTS}

Liver damage is one of the clear signs of PCB poisoning in humans. In the present study, in vivo dose and duration dependent Aroclor 1254 toxicity to membrane bound ion dependent ATPases was estimated from the hepatic cells of adult male Swiss albino mice. The results of total ATPase activity showed the inhibition in both the doses $\left(0.1\right.$ and $\left.1 \mathrm{mg} \mathrm{kg}^{-1} \mathrm{~d}\right)$ after 4 and 12 days exposure durations. The highest inhibition was observed in $0.1 \mathrm{mg} \mathrm{kg}^{-1} \mathrm{~d}$ dose. However, after 8 days of exposure, stimulation in the enzyme activity was observed in both the toxicated groups (Fig. 1a). Similar trend was observed in $\mathrm{Na}^{+}-\mathrm{K}^{+}$and $\mathrm{Ca}^{++}$ATPases also (Fig. 1b-1c). The effect of Aroclor 1254 does not seem to be dose dependent, so these results suggesting the time dependent affects on some membrane bound ion dependent ATPases.

The activity of $\mathrm{Mg}^{++}$ATPase was inhibited in 0.1 $\mathrm{mg} \mathrm{kg}^{-1} \mathrm{~d}$ dose after 4 and 12 days exposure durations, stimulated in $1 \mathrm{mg} \mathrm{kg}^{-1} \mathrm{~d}$ dose group after 4 days of exposure duration and inhibited after 12 days of exposure in Aroclor. However, after 8 days of exposure, stimulation was observed in $0.1 \mathrm{mg} \mathrm{kg}^{-1}$ day dose group followed by inhibition in $1 \mathrm{mg} \mathrm{kg}^{-1} \mathrm{~d}$ toxicated group (Fig. 1d). These alterations were may be due to that exposure of Aroclor 1254 which causes more damage to the permeability and general metabolic activity of the hepatic cell. It is also possible that the imposed stress by the PCB was affecting the cellular transmembrane movement and cell tried to stabilize it by enhancing or inhibiting the ion channels. 


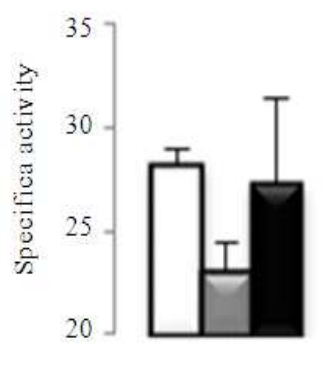

Total ATPase
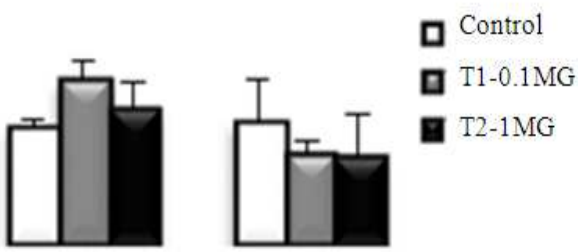

(a)

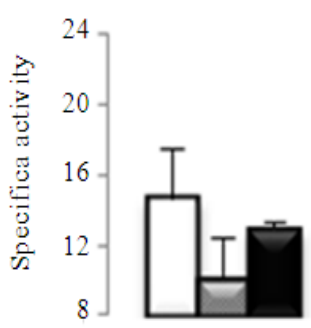

$\mathrm{Na}^{8} \mathrm{~K}^{8}$ ATPase
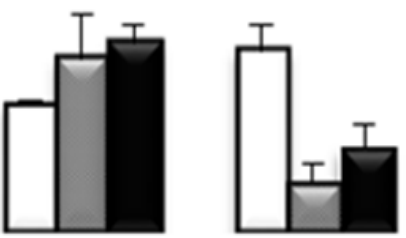

口 Control

प T1-0.1MG

(b)

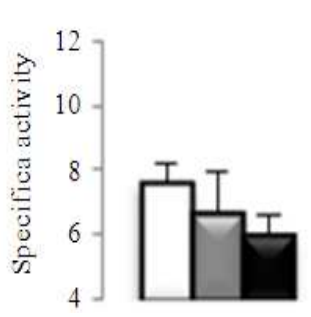

$\mathrm{Ca}^{* *}$ ATPase
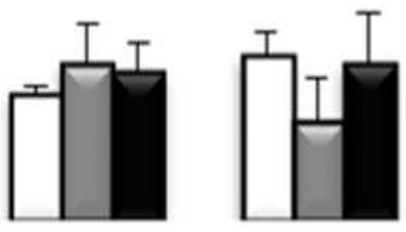

Control

口 $\mathrm{T} 1-0.1 \mathrm{MG}$

品 2 -1MG

(c)

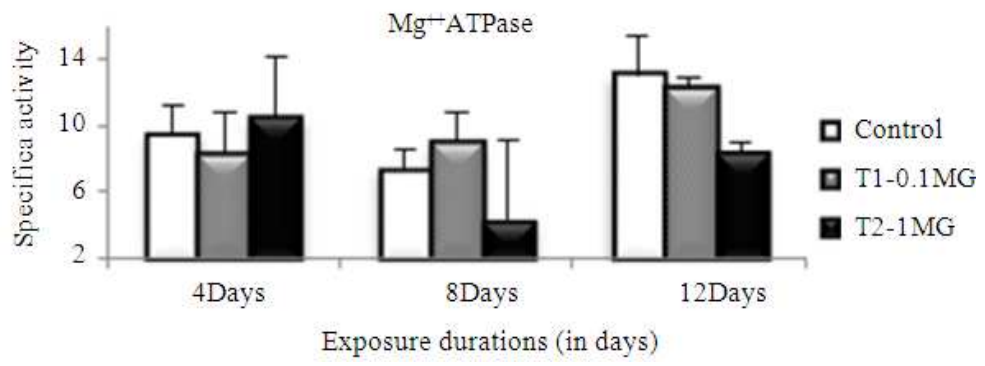

(e)

Fig. 1. Dose and duration dependent changes in the specific activities of different ATPases after Aroclor 1254 intoxication

\section{DISCUSSION}

Liver, being the largest gland and main detoxifying organ of the body is a principal location for various metabolic processes.

Since the ATPases are responsible for trans-membrane movements of ions, it is possible that the Aroclor affected the transport channels of the liver cells by altering the enzyme activity (Yoshimura et al., 1985). The results of two-factor ANOVA showed a predominantly exposure duration dependent effects of Aroclor (Table 1). However, the Student's t-test performed between the control and toxicated groups showed variations in different enzymes studied in liver tissue. In case of total ATPase, significant variations were observed in 4 and 8 days of exposure durations between control and lowest dose but no significance was observed in higher dose in most of the enzymes studied (Table 2). 
Table 1. Result of Two-factor ANOVA between control and toxicated groups

\begin{tabular}{lllll}
\hline Sources of variation & Total & $\mathrm{Na}^{+}-\mathrm{K}^{+}$ & $\mathrm{Ca}^{++}$ & $\mathrm{Mg}^{++}$ \\
\hline Amongst doses & 0.91 & $5.85^{*}$ & $5.21^{*}$ & $13.62^{*}$ \\
Within durations & $3.75^{*}$ & $22.61^{*}$ & $6.44^{*}$ & $10.82^{*}$ \\
\hline
\end{tabular}

* Significant at $\mathrm{P}=0.05(\mathrm{~F}$ crit $(\mathrm{df}=3,8)=3.01)$

$* *$ Significant at $\mathrm{P}=0.05(\mathrm{~F}$ crit $(\mathrm{df}=8,35)=2.36)$

Table 2. Result of t-test between control and individual exposure duration within each dose

\begin{tabular}{|c|c|c|c|c|c|c|c|c|}
\hline & \multicolumn{2}{|l|}{ Total } & \multicolumn{2}{|l|}{$\mathrm{Na}^{+}-\mathrm{K}^{+}$} & \multicolumn{2}{|l|}{$\mathrm{Ca}^{++}$} & \multicolumn{2}{|l|}{$\mathrm{Mg}^{++}$} \\
\hline & $0.1 \mathrm{mg}$ & $1 \mathrm{mg}$ & $0.1 \mathrm{mg}$ & $1 \mathrm{mg}$ & $0.1 \mathrm{mg}$ & $1 \mathrm{mg}$ & $0.1 \mathrm{mg}$ & $1 \mathrm{mg}$ \\
\hline 4 days & $13.12^{*}$ & 0.86 & $3.27^{*}$ & 1.13 & $2.83^{*}$ & $3.44^{*}$ & 1.03 & 0.70 \\
\hline 8 days & $2.74^{*}$ & 1.10 & 1.52 & $2.77^{*}$ & 1.09 & 0.71 & 1.09 & $2.52^{*}$ \\
\hline 12 days & 0.77 & 0.73 & $14.74^{*}$ & $8.07^{*}$ & $3.69^{*}$ & 0.34 & 0.24 & $2.60^{*}$ \\
\hline
\end{tabular}

*Significant at $\mathrm{P}=0.05(\mathrm{~T}$ crit. $=2.447)$

Table 3. Result of Single factor ANOVA between individual exposure durations within each group

\begin{tabular}{lrclc}
\hline & Total & $\mathrm{Na}^{+}-\mathrm{K}^{+}$ & $\mathrm{Ca}^{++}$ & $\mathrm{Mg}^{++}$ \\
\hline Control & 1.31 & 3.53 & 3.24 & $4.53^{*}$ \\
$0.1 \mathrm{mg}$ & $28.47^{*}$ & $29.00^{*}$ & $6.60^{*}$ & 1.98 \\
$1 \mathrm{mg}$ & 3.61 & $27.96^{*}$ & $5.86^{*}$ & $19.38^{*}$ \\
\hline
\end{tabular}

*Significant at $\mathrm{p}=0.05(\mathrm{~F}$ crit. $=4.26)$

The results of the single-factor ANOVA showed high significant variations between the exposure durations in most of the enzymes studied (Table 3), possibly governed by a predominantly exposure duration dependent effects (Lakshmi et al., 1991). This may also be due to the fact that the Aroclor, being a lipid soluble compound, took different routes to produce the toxicity in the membrane bound water soluble enzyme systems (Pathak and Kundu, 2011). Few earlier studies on the susceptibility of different ATPases to organochlorine pesticides have also been expressed similar possibilities (Cutkomp et al., 1982). These studies indicated that the degree of enzyme inhibition or stimulation dependent upon the type of ATPase, tissue, animal species and compounds used (Doherty, 1984). The results of the present study obviously answer the first hypotheses as predominantly exposure duration dependent effects. The use of an unpurified enzyme preparation prohibits the unequivocal determination of the mechanism involved in activity, these compounds are not specific effects for one type of ATPase suggested the possibility that more than one factor might have been involved (Pathak and Kundu, 2011) answering the second hypothesis. Similarly, the degree of lipophilicity of these compounds alone cannot explain the observed inhibition, due to the reported insensitivity of rat liver mitochondrial $\mathrm{Mg}^{++}$-ATPase to the highly lipophilic compound mirex (Desaiah et al.,
1977), but suggestive of a more complex indirect chain of events therein (Pathak and Kundu, 2011).

\section{CONCLUSION}

The observations suggested that the alteration in the enzyme activity was possibly due to the oxidative stress generated by Aroclor 1254. The results indicated that the membrane bound hydrophilic ATPases were indeed affected by the hydrophobic Aroclor, but the effects were possibly indirect through complex chain of reactions exhibited by the cells. These alterations were may be due to that exposure of Aroclor 1254 which causes more damage to the permeability and general metabolic activity of the hepatic cell. It is also possible that the imposed stress by the PCB was affecting the cellular transmembrane movement and cell tried to stabilize it by enhancing or inhibiting the ion channels.

\section{ACKNOWLEDGMENT}

Reachers are thankful to UGC, Govt. of India, New Delhi for supporting this study through its CAS Programme. UGC is also thankfully acknowledged for a Meritorious Research Fellowship awarded to the senior author.

\section{REFERENCES}

ATSDR, 1995. Toxicological Profile for Polychlorinated Biphenyls. Prepared by Research Triangle Institute, under Contract No. 205-93-0606 for ATSDR, Public Health Service, U.S. Department of Health and Human Services. 
Carter, J.R and S.I. Koo, 1984. Effects of dietary Aroclor ${ }^{\circledR}$ 1254 (PCBs) on serum levels of lipoprotein cholesterol and tissue distribution of zinc, copper and calcium in Fischer rats. Nutr. Rep. Int., 29: 223-232.

Carter, J.W., 1985. Effects of dietary PCBs (Aroclor ${ }^{\circledR}$ 1254) on serum levels of lipoprotein cholesterol in Fischer rats. Bull. Environ. Contam. Toxicol., 34: 427-431. PMID: 3919789

Cutkomp, L.K., R.B. Koch and D. Desaiah, 1982. Inhibition of ATPases by Chlorinated Hydrocarbons. In: Insecticide Mode of Action, Coats, J.R. (Ed.), Academic Press, New York, ISBN-10: 0323140513, pp: 45-69.

Desaiah, D., I.K. Ho and H. Mehendale, 1977. Effects of ketone and mirex on mitochondrial Mg2+-ATPase activity in rat liver. Toxicol. Applied Pharmacol., 39: 219-228. DOI: 10.1016/0041-008X(77)90155-7

Doherty, J.D., 1984. Insecticides Affecting Ion Transport. In: Differential Toxicities of Insecticides and Halogenated Aromatics, Matsumura, F. (Ed.), Pergamon Press, New York, ISBN-10: 0080298265, pp: 423-452.

Fiske, C.F. and Y. Subbarow, 1952. The colorimetric determination of phosphorus. J. Biol. Chem., 66: 375-400.

Hale, R.C, M. Alaee, J. Manchester-Neesvig, H. Stapleton and M. Ikonomou, 2003. Polybrominated diphenyl ether flame retardants in the North American Environment. Environ. Int., 29: 771-779. DOI: 10.1016/S0160-4120(03)00113-2

Hansen, L.G., 1994. Halogenated Aromatic Compounds. In: Basic Environmental Toxicology, Cockerham, L.G. and B.S. Shane (Eds.), CRC Press Inc., Boca Raton, Fla., ISBN-10: 0849388511, pp: 199-230.

Koch, R.B., 1972. Polychlorinated biphenyls. Effect of long-term exposure on ATPase activity in fish, Pimephales promelas. Bull. Environ. Contam. Toxicol., 7: 87-92. PMID: 4274091

Lakshmi, R., R. Kundu, E. Thomas and A.P. Mansuri, 1991. Mercuric chloride-induced inhibition of different ATPases in the intestine of mudskipper, Boleophthalmus dentatus. Ecotoxicol. Environ. Safety, 21: 121-125. DOI: 10.1016/01476513(91)90003-8
LaRocca, P.T. and G.P. Carlson, 1979. The effect of polychlorinated biphenyls on adenosine triphosphatase activity. Toxicol. Applied Pharmacol., 48: 185-192. DOI: 10.1016/S0041008X(79)80021-6

Lowry, O.H., N.J. Rosebrough, A.L. Farr and R.J. Randall, 1951. Protein measurement with the Folin phenol reagent. J. Biol. Chem., 193: 265-275. PMID: 14907713

Lu, P.Y., 1989. The Installation Restoration Program Toxicology Guide. 1st Edn., Defense Technical Information Center, pp: 673.

Pathak, S. and R. Kundu, 2011. Short-term PCB (Aroclor 1254) toxicity on few phosphatases in mice brain. Dose Response. (in press).

Price, S.C., S. Ozalp and R. Wever, 1988. Thyroid hyperactivity caused by hypolipidaemic compounds and polychlorinated biphenyls: The effect of coadministration in the liver and thyroid. Proceedings of the European Society of Toxicology, Strasbourg, Sept. 17-19, Springer-Verlag, New York, pp: 85-92.

Sokal, R.R. and F.J. Rohlf, 1969. Biometry. 1st Edn., W.H. Freeman and Company, San Francisco, pp: 260.

Van Birgelen, A.P., D.K.J. Van, K.M. Fase, I. Bol and H. Poiger, 1994. Toxic potency of 3,3',4,4',5pentachlorobiphenyl relative to and in combination with 2,3,7,8-tetrachlorodibenzo-p-dioxin in a subchronic feeding study in the rat. Toxicol. Applied Pharmacol., 127: 209-211. PMID: 8048064

Yoshimura, H., S. Yoshihara, N. Koga, K. Nagata and I. Wada, 1985. Inductive effect on hepatic enzymes and toxicity of congeners of PCBs and PCDFs. Environ. Health Perspect., 59: 113-119. PMID: 3921354

Zaugg, W.S., 1982. A simplified preparation for ATPase determination in gill tissue. Can. J. Fish Aquatic Sci., 39: 215-217. 